\title{
Dental Management of Low Socioeconomic Level Patients Before Radiotherapy of the Head and Neck with Special Emphasis on the Prevention of Osteoradionecrosis
}

\author{
Paulo Rogério Ferreti BONAN ${ }^{1}$ \\ Márcio Ajudarte LOPES ${ }^{2}$ \\ Fábio Ramoa PIRES ${ }^{3}$ \\ Oslei Paes de ALMEIDA²
}

\author{
${ }^{1}$ Department of Oral Pathology and Semiology, \\ School of Dentistry, State University of Montes Claros, Montes Claros, MG, Brazil \\ ${ }^{2}$ Department of Oral Pathology and Semiology, School of Dentistry, State University of Campinas, Piracicaba, SP, Brazil \\ ${ }^{3}$ Department of Oral Pathology, School of Dentistry, State University of Rio de Janeiro, Rio de Janeiro, RJ, Brazil
}

\begin{abstract}
Head and neck cancer patients need to receive dental care previously to radiotherapy. Even patients who regularly visit dental offices need special attention including profilatic and curative treatments. The purposes of this study were to evaluate the dental status of Brazilian head and neck squamous cell carcinoma patients with low socioeconomic level as well as to discuss the dental treatment performed and the oral side effects of radiotherapy. Forty patients with head and neck squamous cell carcinoma received dental care and dental extractions prior to radiotherapy and were were followed up for a mean period of 28.7 months after the cancer treatment. Before radiotherapy, 28 patients were dentulous and 12 edentulous, and all of them had poor oral health and hygiene. The most common treatment performed were dental extraction and 23 patients had 8.6 teeth extracted on average. One out of $9(11.1 \%)$ patients developed radiation caries and 5 out of 23 cases (21.3\% - Group I) developed osteoradionecrosis, being only 1 case associated with previous dental extraction. Brazilian low-socioeconomic level patients with head and neck cancer were submitted to multiple dental extractions due to poor dental condictions and inadequate oral care. The dental treatment did not prevent osteoradionecrosis, which presumably presented a multifactorial etiology in most cases.
\end{abstract}

Key Words: radiotherapy, dental care, osteoradionecrosis, low-socioeconomic level patients.

\section{INTRODUCTION}

Patients with head and neck squamous cell carcinoma elected to radiotherapy need to receive preventive dental treatment. A study with 250 patients examined just before radiotherapy showed that $68 \%$ of them needed immediate dental care (1). Even patients who regularly visit dental offices need specific dental care before radiotherapy, including dental extractions (2). It is also desired that patients achieve a good level of oral hygiene before radiotherapy (3). Dental extractions and periodontal treatment prior to radiotherapy prevent the development of radiation caries, progression of periodontal disease and osteoradionecrosis (4-5). It is well accepted that tooth extraction should be avoided even after many years of head and neck radiotherapy (6). Decreased local vascularization and its consequent radiation impaired healing capacity, particularity in the mandible, is the main cause of osteoradionecrosis (7). Although the need of dental treatment before radiotherapy of head and neck is imperative, few reports emphasize this aspect related to oral cancer (1-2).

Males in their 50's or older with low socioeconomic level have the typical profile of head and neck

Correspondence: Dr. Paulo Rogério Ferreti Bonan, Avenida Corinto Crisóstomo Freire, 600, apto 305H, 39401-365 Montes Claros, MG, Brasil. Tel: +55-38-3213-5759. Fax: +55-38-3229-8082. e-mail: pbonan@yahoo.com 
squamous cell carcinoma patients in Brazil. Even in developed countries, head and neck squamous cell carcinoma patients present poor dental condiction (8). Elderly people in Brazil usually have poor oral hygiene, advanced periodontal disease and severe tooth decay (910). The purposes of this study were to evaluate dental status of Brazilian head and neck squamous cell carcinoma patients with low socioeconomic level as well as to discuss the dental treatment performed and the oral side effects of radiotherapy, with emphasis on the prevention of osteoradionecrosis.

\section{MATERIAL AND METHODS}

This search proposal was submitted to review by the Ethics in Research Committee of the School of Dentistry of Piracicaba (UNICAMP, Brazil) and the study design was approved.

Forty patients with head and neck squamous cell carcinoma submitted to radiotherapy (teleradiotherapy from a $6 \mathrm{MeV}$ linear accelerator) were recruited from the Center Specialized in Oncology (CEON) in the city of Piracicaba, Brazil, and enrolled in this study. All patients had low socioeconomic level and poor oral health.

Before radiotherapy, general data and risk factors for oral cancer were investigated and all patients received a full mouth examination including dental evaluation and panoramic radiographs. Oral care instructions were given and all patients were followed during and after radiotherapy. Edentulous patients were instructed not to use the dentures during radiotherapy. The presence of caries and periodontal disease was assessed clinically. Panoramic radiographs were performed to assess the presence of periapical pathosis, impacted teeth and general bone conditions (11-12). When the teeth were preserved, a fluoride therapy was prescribed, consisting of daily topical applications of $1.23 \%$ sodium fluoride gel onto the surfaces of all teeth using the brush technique to have maximal protective effect. Dental treatment protocols included restorative and periodontal treatments as well as extractions of hopeless teeth with severe periodontal disease and extensive caries (11-12).

Data regarding radiation caries and osteoradionecrosis or any other dental problem were followed up for a mean period of 28.7 months, ranging from 2 to 48 months.

\section{RESULTS}

Patients' age, gender, smoking habits, tumor site, clinical stage, treatment modalities and follow-up are shown on Table 1. Mean age was 58.8 years, ranging from 34 to 83 years and 37 (92.5\%) patients were male. Most patients were smokers (65\%) or referred past tobacco use history (32.5\%), with decades of continuous consumption of cigarettes. Only one female, the youngest of the group, reported to be a non-smoker. Eleven patients (27.5\%) referred chronical alcohol consumption and 26 patients (65\%) had past alcohol use history. Floor of the mouth (11 cases) and tongue (11 cases) were the most frequent sites for head and neck squamous cell carcinoma and most cases were diagnosed in advanced stages [82.5\% - TNM (Tumor-Node-Metastasis) stages 3 and 4]. Radiotherapy exclusively or associated with chemotherapy (70\%) were the most frequent type of treatment, followed by association of surgery and radiotherapy (30\%). Data about present teeth, radiographic findings, denture use and dental treatment performed before radiotherapy are shown on Table 2. Twenty-eight (70\%) patients were dentulous (10.4 teeth on average), and 12 were edentulous (30\%). Dental caries and severe periodontal bone disease were common. Radiographs showed 3 impacted teeth and 14 periapical lesions. From the 28 dentulous patients, 12 (43\%) presented caries and 26 (93\%) had severe periodontal disease. For most dentate patients, treatment of choice was extraction of all or some teeth. When teeth were preserved, patients received oral care instructions about toothbrushing and dental floss use, and periodontal scaling was performed. Among the 28 dentulous patients, 23 (82\%) had dental extractions with an average of 8.6 extracted teeth per patient (Group I), while 17 patients (42.5\%) did not had any tooth extracted (Group II). Twenty-two patients (55\%) were denture wearers and all of them were instructed to remove the partial and total dentures during radiotherapy.

The patients received a 6,743.5 cGy dose on average, ranging from 4,500 to 9,000 cGy. One out 9 (11.1\%) dentulous patients (post-radiotherapy) had radiation caries and restorations were placed on the decayed teeth. Five patients (21.3\%) developed osteoradionecrosis and all of them belonged to Group I, being statistically different from Group II (no osteoradionecrosis case), as detected by the chi-square test $(\mathrm{p}<0.05)$. 
Table 1. Age, gender, tobacco use, tumor site, clinical stage, total radiation doses (cGy), treatment modalities and follow-up of 40 patients with head and neck squamous cell carcinoma.

\begin{tabular}{|c|c|c|c|c|c|c|c|c|c|}
\hline \multirow[t]{2}{*}{ Patient } & \multirow[t]{2}{*}{ Age } & \multirow[t]{2}{*}{ Gender } & \multicolumn{2}{|c|}{ Tobacco } & \multirow[t]{2}{*}{ Tumor site } & \multirow{2}{*}{$\begin{array}{c}\text { Clinical Stage } \\
\text { (UICC) }\end{array}$} & \multirow{2}{*}{$\begin{array}{c}\text { Total radiation } \\
\text { dose (cGy) }\end{array}$} & \multirow{2}{*}{$\begin{array}{r}\text { on Treatment } \\
\text { Mode }\end{array}$} & \multirow{2}{*}{$\begin{array}{r}\text { Follow-up } \\
\text { (mths) }\end{array}$} \\
\hline & & & Use & Time (yrs) & & & & & \\
\hline 1 & 56 & Male & Smoker & 25 & Floor of Mouth & 4 & 7000 & Radio & 48 \\
\hline 2 & 58 & Male & Smoker & $>30$ & Floor of Mouth & 4 & 8100 & Radio + Chem & 48 \\
\hline 3 & 61 & Male & Smoker & $>30$ & Floor of Mouth & 4 & 7100 & Radio & 46 \\
\hline 4 & 75 & Male & Smoker & $>30$ & Tongue & 3 & 7000 & Radio & 46 \\
\hline 5 & 58 & Male & Smoker & 15 & Buccal Mucosa & 4 & 7440 & Radio & 46 \\
\hline 6 & 74 & Male & Ex-Smoker & $>30$ & Floor of Mouth & 4 & 7000 & Radio + Chem & 45 \\
\hline 7 & 83 & Male & Smoker & $>30$ & Floor of Mouth & 3 & 7000 & Radio & 45 \\
\hline 8 & 62 & Male & Ex-Smoker & $>30$ & Tongue & 4 & 7100 & Surg + Radio + Chem & 37 \\
\hline 9 & 52 & Male & Smoker & $>30$ & Tongue & 2 & 7000 & Surg + Radio & 42 \\
\hline 10 & 47 & Male & Ex-Smoker & 25 & Oropharynx & 4 & 7000 & Radio & 43 \\
\hline 11 & 46 & Male & Smoker & $>30$ & Tongue & 4 & 5040 & Radio & 39 \\
\hline 12 & 64 & Male & Smoker & $>30$ & Oropharynx & 4 & 7000 & Radio & 40 \\
\hline 13 & 69 & Male & Smoker & $>30$ & Buccal Mucosa & 4 & 6840 & Radio & 40 \\
\hline 14 & 53 & Female & Smoker & 25 & Floor of Mouth & 2 & 7120 & Radio & 38 \\
\hline 15 & 63 & Female & Smoker & 25 & Buccal Mucosa & 4 & 7000 & Radio + Chem & 38 \\
\hline 16 & 64 & Male & Ex-Smoker & $>30$ & Oropharynx & 4 & 6000 & Radio + Chem & 37 \\
\hline 17 & 48 & Male & Ex-Smoker & $>30$ & Soft Palate & 3 & 6000 & Surg + Radio & 42 \\
\hline 18 & 54 & Male & Ex-Smoker & $>30$ & Larynx & 4 & 7000 & Surg + Radio & 36 \\
\hline 19 & 63 & Male & Smoker & $>30$ & Oropharynx & 4 & 7000 & Radio & 31 \\
\hline 20 & 41 & Male & Smoker & $>30$ & Soft Palate & 1 & 4600 & Radio & 5 \\
\hline 21 & 40 & Male & Smoker & 25 & Soft Palate & 2 & 7000 & Surg + Radio & 25 \\
\hline 22 & 70 & Male & Ex-Smoker & $>30$ & Tongue & 4 & 7200 & Surg + Radio & 6 \\
\hline 23 & 63 & Male & Smoker & $>30$ & Tongue & 2 & 6000 & Surg + Radio & 20 \\
\hline 24 & 54 & Male & Smoker & 25 & Tongue & 2 & 7200 & Radio & 21 \\
\hline 25 & 73 & Male & Ex-Smoker & 25 & Tongue & 3 & 7200 & Radio & 24 \\
\hline 26 & 50 & Male & Ex-Smoker & 15 & Tongue & 4 & 6300 & Surg + Radio + Chem & 27 \\
\hline 27 & 58 & Male & Smoker & $>30$ & Floor of Mouth & 4 & 9000 & Radio + Chem & 28 \\
\hline 28 & 74 & Male & Smoker & $>30$ & Retromolar & 2 & 7200 & Radio & 32 \\
\hline 29 & 36 & Male & Ex-Smoker & 15 & Rhinopharynx & 3 & 5040 & Radio & 32 \\
\hline 30 & 46 & Male & Smoker & 25 & Floor of Mouth & 4 & 7040 & Surg + Radio & 28 \\
\hline 31 & 65 & Male & Smoker & $>30$ & Soft Palate & 4 & 7000 & Surg + Radio & 21 \\
\hline 32 & 34 & Female & Non-Smoker & --- & Retromolar & 4 & 6900 & Surg + Radio & 41 \\
\hline 33 & 62 & Male & Ex-Smoker & 25 & Tongue & 3 & 6000 & Surg + Radio & 3 \\
\hline 34 & 58 & Male & Smoker & $>30$ & Floor of Mouth & 2 & 6600 & Radio & 2 \\
\hline 35 & 76 & Male & Ex-Smoker & $>30$ & Alveolar Ridge & 4 & 6000 & Surg + Radio & 5 \\
\hline 36 & 64 & Male & Smoker & $>30$ & Maxillary Sinus & 3 & 7000 & Radio +Chemo & 15 \\
\hline 37 & 52 & Male & Smoker & $>30$ & Tongue & 4 & 7200 & Radio + Chemo & 22 \\
\hline 38 & 78 & Male & Smoker & $>30$ & Floor of Mouth & 4 & 7000 & Radio + Chemo & 4 \\
\hline 39 & 52 & Male & Ex-Smoker & $>30$ & Larynx & 4 & 4500 & Surg + Radio & 8 \\
\hline 40 & 54 & Male & Smoker & 25 & Floor of Mouth & 4 & 7020 & Surg + Radio & 6 \\
\hline
\end{tabular}

UICC = International Union against Cancer Tumor-Node-Metastasis Staging System. Surg = surgery; Radio = radiotherapy; Chemo = chemotherapy. 
Table 2. Number of present teeth, denture use, radiographic findings and dental treatment before radiotherapy of 40 patients with head and neck squamous cell carcinoma.

\begin{tabular}{|c|c|c|c|c|}
\hline Patient & N. of teeth & Radiographic Findings & Denture Use & Dental Treatment \\
\hline 1 & 13 & Periapical lesions (3) & None & Exodontia (13 teeth) \\
\hline 2 & 22 & Periapical lesion (1) & CUD & Exodontia (22 teeth) \\
\hline 3 & 9 & None & CUD & Exodontia (9 teeth) \\
\hline 4 & 0 & None & None & Edentulous \\
\hline 5 & 0 & Osteosclerosis & CUD + CLD & Edentulous \\
\hline 6 & 9 & None & CUD & Exodontia (9 teeth) \\
\hline 7 & 1 & None & None & Exodontia (1 tooth) \\
\hline 8 & 12 & None & CUD & Exodontia (12 teeth) \\
\hline 9 & 28 & None & None & $\begin{array}{l}\text { Exodontia }(5 \text { teeth })+\text { periodontal scaling }+ \\
\text { fluoride therapy }+ \text { oral heath care }\end{array}$ \\
\hline 10 & 0 & None & CUD & Edentulous \\
\hline 11 & 0 & None & None & Edentulous \\
\hline 12 & 0 & None & CUD + CLD & Edentulous \\
\hline 13 & 9 & Periapical lesions (6) & None & Exodontia (9 teeth) \\
\hline 14 & 7 & None & None & Exodontia (7 teeth) \\
\hline 15 & 19 & Periapical lesion (1) + Impacted tooth (1) & None & Exodontia (19 teeth) \\
\hline 16 & 0 & None & CUD + CLD & Edentulous \\
\hline 17 & 22 & Osteosclerosis & PUP & Fluoride therapy + oral health care \\
\hline 18 & 0 & None & CUD + CLD & Edentulous \\
\hline 19 & 9 & None & CUD & Exodontia (9 teeth) \\
\hline 20 & 17 & None & None & $\begin{array}{l}\text { Exodontia }(6 \text { teeth })+\text { periodontal scaling + } \\
\text { fluoride therapy + oral health care }\end{array}$ \\
\hline 21 & 12 & None & PUP & Exodontia (12 teeth) \\
\hline 22 & 2 & Impacted tooth (1) & None & Exodontia (1 tooth) \\
\hline 23 & 13 & Periapical lesions (3) & None & Exodontia (13 teeth) \\
\hline 24 & 14 & None & None & Exodontia (14 teeth) \\
\hline 25 & 0 & None & CUD+CLD & Edentulous \\
\hline 26 & 12 & Tumor rarefation & PLD & Exodontia (12 teeth) \\
\hline 27 & 16 & Tumor rarefation & None & Exodontia (16 teeth) \\
\hline 28 & 5 & None & None & Exodontia (5 teeth) \\
\hline 29 & 23 & None & PUD & Fluoride therapy + oral health care \\
\hline 30 & 19 & None & PLD & Exodontia (19 teeth) \\
\hline 31 & 0 & None & CUD & Edentulous \\
\hline 32 & 31 & None & None & Fluoride therapy + oral health care \\
\hline 33 & 25 & None & None & $\begin{array}{l}\text { Exodontia (4 teeth) + fluoride therapy } \\
\text { + oral health care }\end{array}$ \\
\hline 34 & 1 & Impacted tooth (1) & PUD & Exodontia (1 tooth) \\
\hline 35 & 0 & None & CLD & Edentulous \\
\hline 36 & 0 & None & CUD & Edentulous \\
\hline 37 & 26 & None & None & Fluortherapy + oral health care \\
\hline 38 & 13 & None & None & Exodontia (13 teeth) \\
\hline 39 & 15 & None & PLD & Fluoride therapy + oral care \\
\hline 40 & 17 & None & PLD & $\begin{array}{l}\text { Exodontia }(9 \text { teeth })+\text { periodontal scaling + } \\
\text { fluoride therapy + oral health care }\end{array}$ \\
\hline
\end{tabular}

CUD = complete upper denture; CLD = complete lower denture; PUD = partial upper denture; PLD = partial lower denture. 
Three cases were associated with multifactorial etiology (high doses of radiation, heavy tobacco and alcohol use, poor systemic condition, malnutrition and even local trauma), one was mainly associated with dental extraction before radiotherapy presenting a nonhealed alveolus, and one was associated with a mandibulectomy performed during cancer treatment. In this last case, none extracted teeth were involved in the necrotic area. All cases affected the mandible and all patients were dentulous prior radiotherapy. From these 5 patients, 4 had total extractions prior radiotherapy due to poor dental conditions including teeth on areas of osteoradionecrosis development. Nevertheless, only one patient (21) presented non healed-alveolus after dental extraction and the others had normal repair after dental surgery. None of them presented periapical lesions. One patient received daily fluor gel and had 4 extractions out of 25 teeth. Two cases of osteoradionecrosis were treated with local antiseptic irrigation, exclusively. One patient was cured and the other patient died due to neoplastic progression 15 months after radiotherapy. Two patients were submitted to local antiseptic irrigation and sequestrectomy. One lesion healed and the other patient still have areas of bone necrosis, and is waiting for hyperbaric oxygen therapy. One patient received 14 dives of hyperbaric oxygen therapy treatment and the lesion healed. Data about the 5 cases of osteoradionecrosis, including the intervals between the dental extractions and osteoradionecrosis onset are shown on Table 3.

\section{DISCUSSION}

In the present study, most patients with head and neck squamous cell carcinoma were middle aged adult males who were chronic tobacco and alcohol consumers and had advanced tumors located floor of the mouth and tongue. Radiotherapy of the head and neck is associated with decreased bone vascularity and repair capacity. Dental treatment before radiotherapy is necessary to avoid dental extractions after radiotherapy $(3,5,13)$. This is particularly true for patients with low socioeconomic levels from underdeveloped countries as Brazil. Even in head and neck squamous cell carcinoma patients from developed countries, poor dental conditions have been reported (8).

In poor countries, several patients with advanced head and neck squamous cell carcinoma are treated exclusively by radiotherapy due to the high-cost and poor prognosis of surgical treatment. It explains why the association between surgical treatment and radiotherapy was less common than radioterapy exclusively

Table 3. Correlation of 5 osteoradionecrosis cases with age, localization, clinical stage, total and daily radiation doses (cGy), oncotherapy, time of tooth extraction before radiotherapy, etiology and time of onset after radiotherapy.

\begin{tabular}{|c|c|c|c|c|c|c|c|c|c|c|}
\hline Patient & Age & Site & $\begin{array}{l}\text { Clinical } \\
\text { Stage } \\
\text { (UICC) }\end{array}$ & $\begin{array}{c}\text { Total } \\
\text { radiation } \\
\text { dose } \\
(\mathrm{cGy})\end{array}$ & $\begin{array}{c}\text { Daily } \\
\text { radiation } \\
\text { dose } \\
(\mathrm{cGy})\end{array}$ & $\begin{array}{l}\text { Dental } \\
\text { treatment }\end{array}$ & Oncotherapy & $\begin{array}{c}\text { Interval } \\
\text { of extraction }\end{array}$ & Etiology & $\begin{array}{l}\text { Time } \\
\text { of onset } \\
\text { (mths) }\end{array}$ \\
\hline 19 & 63 & $\begin{array}{l}\text { Posterior } \\
\text { mandible }\end{array}$ & 4 & 7000 & 200 & TE (9 teeth) & Radio & $10 \mathrm{~d}$ & Multifactorial & 10 \\
\hline 21 & 40 & $\begin{array}{l}\text { Anterior } \\
\text { mandible }\end{array}$ & 2 & 7000 & 200 & TE (12 teeth) & Surg + Radio & $7 \mathrm{~d}$ & $\begin{array}{c}\text { Extraction } \\
\text { prior to Radio }\end{array}$ & -1 \\
\hline 24 & 54 & $\begin{array}{l}\text { Posterior } \\
\text { mandible }\end{array}$ & 2 & 7200 & 180 & TE (14 teeth) & Radio & $10 \mathrm{~d}$ & Multifactorial & 3 \\
\hline 26 & 50 & $\begin{array}{l}\text { Anterior } \\
\text { mandible }\end{array}$ & 4 & 6300 & 180 & TE (12 teeth) & $\begin{array}{l}\text { Surg + Radio + } \\
\text { Chemo }\end{array}$ & $10 \mathrm{~d}$ & Multifactorial & 1 \\
\hline 33 & 62 & $\begin{array}{l}\text { Posterior } \\
\text { mandible }\end{array}$ & 3 & 7000 & 200 & $\begin{array}{c}\text { Extraction of } 4 \\
\text { teeth + fluoride } \\
\text { therapy + oral care }\end{array}$ & Surg + Radio & 2 mths & Mandibulectomy & 1 \\
\hline
\end{tabular}

UICC = International Union against Cancer Tumor-Node-Metastasis Staging System. Surg = surgery; Radio = radiotherapy; Chemo = chemotherapy. $\mathrm{TE}=$ Total extraction . 
or associated with chemotherapy in our data.

In the present study, dental treatment was clearly necessary, as most dentate patients presented severe periodontal disease and caries. Severe to moderate periodontal disease was found in $93 \%$ of dentate patients and $43 \%$ of them also presented caries. The findings of this study are consistent with those of previous works that showed poor oral care status in patients with oral cancer $(3,4,13)$. Other study involving patients with nasopharyngeal carcinoma showed that dental extractions were recommended for $68 \%$ of dentate patients and a mean of 5.9 teeth per patient were indicated to be removed (2). In our study, $82 \%$ of dentate patients needed dental extractions and an average of 8.6 teeth per patient were extracted mostly due to severe periodontal disease. It is important to consider that dental treatment in a patient planned to receive radiotherapy is singular, and may include dental extraction of a tooth that might otherwise receive a more conservative treatment $(2,11)$. Although aconservative approach is indicated in some cases, for patients with limited past dental care, poor oral hygiene and evident dental/periodontal diseases, a more aggressive pre-radiation dental management should be considered (11). In our study, due to the characteristics of the patients, teeth with large caries, severe periodontal disease or periapical lesions were extracted. Only one patient presented radiation caries and no osteoradionecrosis case derived from post-radiotherapy dental management.

The incidence of osteoradionecrosis is variable, ranging from 4.4 to $22 \%$, including patients who had received previous dental treatment $(13,15,16)$. In the present study, the incidence of osteoradionecrosis was $21.3 \%$ (5 out of 23 patients). Post-radiation extractions are only one factor from a multifactorial process of osteoradionecrosis development, which includes daily and total doses of radiation, oncologic treatment, local trauma, habits and poor systemic conditions $(3,13,15,16)$ occurs mainly on tobacco and alcohol users with poor general medical conditions and malnutrition $(3,15)$. From the 5 osteoradionecrosis cases reported in our study, all referred heavy tobacco and alcohol use and presented poor nutritional and general status. Osteoradionecrosis are not always associated with tooth extraction and it may occur in edentulous regions. Two reports showed that osteoradionecrosis developed in 3 out of 22 (13.5\%) edentulous patients and in 15 out of 21 (71.5\%) irradiated patients, without relation to tooth extractions $(13,16)$. Interval for development of osteoradionecrosis is variable, usually within 1 year after radiotherapy, ranging from 2 weeks to 34 months (13). In the present study there was an average of 3.2 months between the end of radiotherapy and osteoradionecrosis onset, ranging from 1 to 10 months. Other risk factors considered for the development of osteoradionecrosis are radiation dose to bone, advanced stage of tumor and surgery $(5,15)$. The mean total radiation dose of our 5 cases of osteoradionecrosis was 6900 cGy. Of these 5 cases, 3 patients presented clinical stage 3 or 4, with advanced tumors, and 2 patients presented stage 2. One case of osteoradionecrosis was associated with partial mandibulectomy performed after a dose of 7000 cGy to the jaws. Extractions before and after radiotherapy may cause osteoradionecrosis (13). According to Epstein et al. (17) the incidence of mandibular osteoradionecrosis is higher in patients having extractions just before radiotherapy or immediately after. Extractions should be carried out at least 2-3 weeks before radiotherapy starts (18). Unfortunattely, some of our patients needed to start radiotherapy 7 to 10 days after tooth extraction; even so, in only one case osteoradionecrosis was considered to be associated with extraction previous to radiotherapy, with short time to alveolar healing. Conservative management for osteoradionecrosis (sequestrectomy and irrigation) was employed in 4 cases with complete healing in 2 cases of these. The efficacy of hyperbaric oxygen therapy is well accepted; it was effective in 1 case. One study demonstrated that of 18 patients who had undergone surgery and hyperbaric oxygen therapy for refractory osteoradionecrosis, 14 patients had complete healing (19). Nevertheless, hyperbaric oxygen therapy use is not consensual because of small differences compared to placebo, and its efficacy must be investigated continuously (20).

Although new techniques of radiotherapy with fewer side effects, as IMRT (modulated-intensity radiation therapy) and brachytherapy are also available in Brazil, few patients have access to these treatment modalities. In summary, most Brazilian patients with low socioeconomic level who are diagnosed with head and neck squamous cell carcinoma need dental extractions before radiotherapy due to severe periodontal disease and caries. Osteoradionecrosis, as a multifactorial process, is still an important problem associated with high total doses, poor systemic and oral health as 
well as tobacco smoking and alcohol use.

\section{RESUMO}

Pacientes portadores de carcinomas espinocelulares em cabeça e pescoço necessitam receber tratamento odontológico antes da radioterapia. Mesmo pacientes que visitam regularmente consultórios odontológicos requerem especial atenção incluindo profilaxias e tratamentos curativos. Os objetivos desse estudo foram avaliar a condição odontológica de 40 pacientes de baixo nível sócio-econômico antes da radioterapia em cabeça e pescoço e discutir o tratamento odontológico realizado. Os pacientes foram acompanhados durante o tratamento oncológico. Antes da radioterapia, 28 pacientes eram dentados e doze edêntulos, sendo que todos esses apresentavam péssimas condições sistêmicas e higiene oral deficiente. $O$ tratamento mais comumente empregado foi a extração dentária e 23 pacientes tiveram a média de 8,6 dentes extraídos (Grupo I). Um em 9 (11,1\%) pacientes desenvolveram cárie por radiação e 5 em 23 (21,73\%) osteorradionecrose, sendo um caso associado a extrações dentárias prévias à radioterapia e outros de origem multifatorial. Pacientes de baixo nível socioeconômico com carcinoma espinocelular em cabeça e pescoço receberam múltiplas extrações dentárias devido à condição dentária precária e má higienização. O tratamento odontológico não preveniu a osteorradionecrose, que apresenta origem multifatorial na maioria dos casos.

\section{REFERENCES}

1. Lizi EC. A case for dental surgeon at regional radiotherapy centres. Brit Dent J 1992;173:24-26.

2. Epstein JB, Emerton S, Lunn R, Le N, Wong FL. Pretreatment assessment and dental management of patients with nasopharyngeal carcinoma. Oral Oncol 1999;35:33-39.

3. Scully C, Epstein JB. Oral health for the cancer patient. Eur J Cancer B Oral Oncol 1996;32B:281-292.

4. Makkonen TA, Kiminki A, Makkonen TK, Nordman E. Dental extractions in relation to radiation therapy of 224 patients. Int J Oral Maxillofac Surg 1987;16:56-64.

5. Maxymiw WG, Wood RE. The role of dentistry in head and neck radio therapy. J Can Dent Assoc 1989;55:193-198.

6. Kanatas AN, Rogers SN, Martin MV. A practical guide for patients undergoing exodontia following radiotherapy to the oral cavity. Dent Update 2002;29:498-503.

7. Maier A, Gaggl A, Klemen H, Santler G, Anegg U, Fell B,
Karcher H, Smolle-Juttner FM, Friehs GB. Review of severe osteoradionecrosis treated by surgery alone or surgery with postoperative hyperbaric oxygenation. Brit J Oral Maxillofac Surg 2000;38:173-176.

8. Lockhart PB, Clark J. Pretherapy dental status of patients with malignant condictions of the head and neck. Oral Surg Oral Med Oral Pathol 1994;77:236-241.

9. Rosa AG, Fernandez RA, Pinto VG, Ramos L. Oral health status in people 60 years old or older in the municipality of Sao Paulo (Brazil). Rev Saúde Pública 1992;26:155-160.

10. Pereira AC, Castellanos RA, da Silva SR, Watanabe MG, Queluz DP, Meneghim MC. Oral health and periodontal status in Brazilian elderly. Braz Dent J 1996;7:97-102.

11. Epstein JB, Stevenson-Moore P. Periodontal disease and periodontal management in patients with cancer. Oral Oncol 2001;37:613-619.

12. Tugnait A, Clerehugh V, Hirschmann PN. The usefulness of radiographs in diagnosis and management of periodontal diseases: a review. J Dent 2000;28:219-226.

13. Widmark G, Sagne S, Heikel P. Osteoradionecrosis of the jaws. Int J Oral Maxillofac Surg 1989;18:302-306.

14. Maier H, Zoller J, Herrmann A, Kreiss M, Heller WD. Dental status and oral hygiene in patients with head and neck cancer. Otolaryngol Head Neck Surg 1993;108:655-661.

15. Kluth EV, Jain PR, Stuchell RN, Frich JC. A study of factor contributing to the development of osteoradionecrosis of the jaws. J Prosthet Dent 1988;59:194-201.

16. Morrish RB, Chan E, Silverman S, Meyer J, Fu KK, Greenspan D. Osteoradionecrosis in patients irradiated for head and neck carcinoma. Cancer 1981;48:1980-1983.

17. Epstein JB, Rea G, Wong FL, Spinelli J, Stevenson-Moore P. Osteonecrosis: a study of the relationship of dental extractions in patients receiving radiotherapy. Head Neck Surg 1987;4854.

18. Epstein JB, Wong FL, Stevenson-Moore P. Osteoradionecrosis: clinical experience and the proposal for classification. J Oral Maxillofac Surg 1987;45:104-110.

19. Curi MM, Dib LL, Kowalski LP. Management of refractory osteoradionecrosis of the jaws with surgery and adjunctive hyperbaric oxygen therapy. Int J Oral Maxillofac Surg 2000;29:430-434.

20. Annane D, Depondt J, Aubert P, Villart M, Gehanno P, Gajdos $\mathrm{P}$, Chevret S. Hyperbaric oxygen therapy for radionecrosis of the jaw: a randomized, placebo-controlled, double-blind trial from the ORN96 study group. J Clin Oncol 2004;22:48934900 .

Accepted September 11, 2005 